\title{
Persecution of Indian Women: An Analysis on The Most Heinous Cases of Rape and Sexual Abuse of Women
}

\author{
Umme Habiba
}

Ph. D (Human Rights), Department of Political Science, Aligarh Muslim University, Aligarh

\begin{tabular}{|c|c|}
\hline ARTICLE INFO & ABSTRACT \\
\hline $\begin{array}{l}\text { Keywords: } \\
\text { Women } \\
\text { Persecution } \\
\text { Abuses } \\
\text { Victimization } \\
\text { Rape } \\
\text { Sexual Abuse }\end{array}$ & $\begin{array}{l}\text { At the point when we discuss about atrocities against women, we } \\
\text { don't allude to some new happenings yet it is an old phenomenon that } \\
\text { has been permitted to go on. All through the ages from one period to } \\
\text { another period women have been left to the abominations and } \\
\text { carelessness. In all social orders, societies, areas or religious } \\
\text { communities' women have been subject to confront brutality from } \\
\text { higher to the lower level and to the present day in India this has come } \\
\text { to an alarming extent. The situation of women in Indian culture has } \\
\text { been held under continuous dormancy while the exploitation against } \\
\text { them is increasing repeatedly. The explanation, most likely, is that } \\
\text { woman is considered as more vulnerable sex when contrasted with } \\
\text { their contrary sex. This paper explains how women are being } \\
\text { exploited in our patriarchal societies. The present paper also } \\
\text { discusses about why women are being neglected in our male } \\
\text { dominated society. The paper will also focus on various incidences } \\
\text { of rape cases that occur in India. }\end{array}$ \\
\hline
\end{tabular}

\section{Introduction}

Atrocities against women is mainly a consequence of gender relations that expect men to be superior to women. Given the subordinate status of women, most of the time women exploitation is viewed as ordinary and get social approval. Indications of viciousness incorporate physical torture, for example, sexual maltreatment and assault, mental brutality through abuse, embarrassment, pressure, coercion, economic or emotional threat, control over speech and actions. In extreme, in most of the known cases deaths is the results. These incidences of viciousness happens in a man - women relationship inside the family, state and society. Normally, domestic violence towards women and young girls, because of different reasons remains hidden. Social and cultural elements are interlinked with the expansion and spread of violent conduct. With various procedures of socialization that people experience, men take up stereotyped gender roles of domination and control, while women take up that of submission, dependence and respect for authority. A female teenager grows up with a consistent feeling of being powerless and need of protection regardless of whether physical social or monetary. This powerlessness has directed her towards abuse at almost every phase of life.

The family mingles its members to acknowledge hierarchical relations communicated in imbalance division of work between the genders and control over distribution of resources. The family and the home is the place the child is exposed to sexual orientation contrasts since birth, and now a days even before birth, in the form of sex-assurance tests prompting foeticide and female child murder. The home, which should be the most secure place, is the place are generally exposed to viciousness (Khanna, 2009).

* Corresponding Author E-Mail Address: umme.rubi@gmail.com 
The World Health Organization (WHO) defines violence as "the intentional use of physical force or power, threatened or actual, against oneself, another person or against a group or community that either results in or has a high likelihood of resulting in injury, deaths, psychological harm, mal-development or deprivation". This definition includes interpersonal violence as well as suicidal behavior and armed conflicts and covers wide range of issues beyond physical threat and intimidation. The typology of violence given by the WHO divides violence into three categories according to who commits the violent act.

Self-directed violence: suicidal behavior and self-abuse

Interpersonal violence: family and intimate partner violence and community violence Collective violence: violence by group against another group or set of individuals as armed conflicts, terrorism, human rights abuse and organized violent crimes.

Brutality, according to these definitions, in this way incorporates criminal utilization of physical power as well as misuse, discrimination , continuation of inconsistent monetary and social structures, the formation of an atmosphere of fear, danger or retaliation, and different types of religio-social and political viciousness. Exploitation is thus, multidimensional experienced in a scope of settings, from private to open, and in the present globalized world, rising above national limits. Violence is regularly an inevitable truth of women's lives, as the social traditions and mentalities that help brutality against them are settled in and regulated at levels-home, family, network, society, and the state.

\subsection{Objectives of the paper}

1. The aim of this paper is to study the deprived conditions of women in the context of India.

2. This paper is an attempt to bring in to light the most heinous incidence of rape cases which occurs in India in our day to day life.

\section{Why Are Women Vulnerable to Violence?}

Atrocities against women is a worldwide occurrence that kills, brutalize, and hurts ladies physically, mentally, and financially. It is one of the most persevering type of human rights infringement that preclude women from securing balance, security, dignity, self-esteem, and opportunity. In spite of the fact that most enlightened social orders condemn brutality against women, actually it is frequently authorized for the sake of social practices and cultural norms. Male centric social orders propagate male control bringing about imbalance inside social structure which thus prompts inconsistent dispersion of intensity and assets. The social and cultural condition, subsequently, enhances women's vulnerabilities and makes them more inclined to viciousness. Maltreatment of intensity and authority by men or rather people with great influence, regularly makes circumstance which reinforce vicious conduct against women (Nigam, 2008).

Exploitation of women in India is not a current or new ongoing issue. It is an age-old phenomenon. Women have been the victims of abuse and rape since the time of her birth. The feeling that a man is superior to women is given to the boys and young girls from the earliest starting point of their life. Sexual maltreatment or abuse of young ladies and ladies in families is normal, yet once in a while announced. In the event that a young girl is assaulted, both she and her family are considered to have been disgraced. Very few assault cases come to public notice. It is basic for the police to be bribed and those families that do report an assault case to the police are at risk to be derided and, lastly, threatened into dropping the case. Among those cases that are attempted, conviction can be won, however the procedure take a normal of eight years, and the sentences are low. Regardless of the way that genuine lewd behavior is wild in India, it for the most part goes unreported in light of the fact that ladies dread that griping will 
pull in negative consideration. In spite of the fact that section 509 of the Indian Panel Code provides for prosecution of harassment, only a handful of cases are recorded; most are dismissed for lack of evidence. In a famous case a female senior officer at Indian Administrative Services (IAS) named Rupan Bajaj Deol, filed a formal complaint against the Director General of Police, K.P.S. Gill. The Indian government made no move against Gill, and the high court only rejected her case, expressing that the government could claim privilege against disclosure of police records. In certain parts of India, sexual exploitation is organized in the act of offering young females as Devdasis, young girls usually from poor families who are formally committed to Hindu divine and goddesses and afterward explicitly exploited; majority of them end up as prostitutes. Marriage, as well, can be dangerous, even for welleducated and employed women. One of the most dramatic types of viciousness against ladies in India is the thing that has come to be known as "dowry deaths." The institution of dowry was legislatively abolished by the Dowry Prohibition Act starting in 1961, but the giving and accepting of dowry persists. Yet, there are different types of savagery against ladies from which the law offers no assurance. Large -scale police brutality against women is a relatively recent phenomenon, but it spreading fast. The rape of women in custody is widespread, especially in the states of Punjab and Kashmir, where police powers have a free hand.

The most common thing about violence in India is taken as the form of violence that is perpetrated against women. There is a UN Declaration on the Elimination of Violence against Women adopted by the United Nations General Assembly in 1993, which is the first international human rights instrument that addresses the issues of violence against women both explicitly and exclusively. It pronounces that the phenomenon violates, impairs or nullifies women's human rights and their exercise of fundamental freedoms. The Declaration defines 'violence against women' as 'any act of gender -based violence that results in or is likely to result in, physical, sexual or psychological harm or suffering to women, including threats of such acts, coercion or arbitrary deprivation of liberty, whether occurring in public or in private life'.

The definition is improved in article 2 of the Declaration, which identifies three areas in which violence commonly takes place:

1. Physical, sexual and psychological violence that occurs in the family, including battering; sexual abuse of female children in the household; dowry-related violence; marital rape; female genital mutilation and other traditional practices harmful to women; non-spousal violence; and violence related to exploitation;

2. Physical, sexual and psychological violence that occurs within the general community; including rape; sexual abuse; sexual harassment and intimidation at work, in educational institutions and elsewhere; trafficking in women; and forced prostitution;

3. Physical, sexual and psychological violence perpetrated or condoned by the State, wherever it occurs (Bhatt,2010).

It has been seen that the most serious danger of savagery originates from the known men members, frequently male relatives or spouses, not from the stranger male persons. In 2001 Amnesty International Publication in Broken Bodies, Shattered Minds recorded that brutality is 'a truly worldwide phenomenon and that the figures may change in various nations, the torment and its causes are similar all through the world' (Nandita, 2008).

What is remarkable is the similarity of the problem that is observed around the world' in reference to a study conducted by John Hopkins University. By including religious, cultural or traditional beliefs various kinds atrocities are not even acknowledged as such, they are simply left unnoticed, condoned or justified. There can be seen number of cases that show women are helpless against savagery regardless of caste, community, age, class, educational level or living arrangement. Women face atrocities at all their sphere of life both inside and outside the family. This is viewed as cultural component in which viciousness against ladies is seen as power that 
drives them into a subordinate position. It is an expression of power relation which is unequal and has led man to dominate woman, eventually leading to discrimination against them. On the other hand, it has also been observed that women suffer from inferior complexity in male dominant society, which is the basic reason for violence.

The lives of a large number of women are affected by savagery against them all through the world, in all kinds of social, financial or educational classes. Brutality pierces all obstructions of culture, custom and religion and hinder their right to participate. It involves additional misery that viciousness against women takes various terrible structures. The instances of female circumcision, child marriage, assault and murder, domestic maltreatment are growing at alarming rate. All are infringement of the most fundamental human rights. In an announcement to the Fourth World Conference on Women in Beijing in September 1995, the United Nations Secretary-General, Boutros-Ghali, said that atrocities against women is a widespread issue that must be universally condemned. However, he said that the problem continues to grow (Savita, 2010).

Although women may be victims of any of the crimes such as 'Murder,' 'Robery', 'Cheating', etc., the crimes which are directed specifically against women are characterized as 'Crimes Against Women'. These are broadly classified under two categories:

\section{(1)The Crimes identified under the Indian Panel Code (IPC)}

a) Rape (Sec.376 IPC)

b) Kidnapping \& Abduction for different purposes (Sec.363-373 IPC)

c) Homicide for Dowry, Dowry Deaths or their attempts (Sec.302/ 304- B of IPC)

d) Torture, both mental and physical (Sec.498-A of IPC)

e) Molestation (Sec.354 of IPC)

f) Sexual harassment (Sec. 509 of IPC)

g) Importation of girls (up to 21 years of age) (Sec.366-B of IPC)

\section{(2)The Crimes Identified under the Special Laws}

Although all laws are not gender specific, the provisions of law affecting women significantly have been reviewed periodically and amendments carried out to keep pace with the emerging requirements. Some Acts which have special provisions to safeguard women and their interests are:

a) Commission of Sati (Prevention) Act, 1987 (3 of 1988).

b) Dowry Prohibition Act, 1961 (28 of 1961).

c) Indecent Representation of Women (Prohibition) Act, 1986.

d) Immoral Traffic (Prevention) Act, 1956.

e) Medical Termination of Pregnancy Act, 1971(34 of 1971).

f) Child Marriage Restraint Act, 1929(19 of 1929).

g) Hindu Marriage Act, 1955 (25 of 1955).

h) Hindu Succession Act, 1956 (3 of 1956).

i) Contract Labour (Regulation \& Abolition) Act, 1970 (37 of 1970).

j) Equal Remuneration Act, 1976 (25 of 1976)

k) Factories Act, 1948 (63 of 1948) as amended in 1976.

1) Maternity Benefits Act, 1961 (53 of 1961)

m)Criminal Law (Amendment) Act, 1983.

n) Special Marriage Act, 1954.

o) The Family Courts Act, 1954.

p) Employees State Insurance Act, 1948

q) Plantation Labour Act, 1951 (Goel, 2004) 


\section{Rape and Sexual Assault}

The rape is the most heinous crime of all the crimes or atrocities committed against women in the society. The Indian Panel Code covers this heinous act under the Section $375 \& 376$ of IPC. According to Section 375 when a man has sexual intercourse with a woman:

(a) Against her will;

(b) With her consent, when her consent has been obtained by putting her / any person in whom she is interested, in fear of death or hurt;

(c) With her consent, when he by deception, makes her believe that he is her lawful husband;

(d) With her consent, given on account of her unsoundness of mind; or intoxication, which she is incapable of understanding the consequences of her consent; or

(e) With or without her consent, when she is under sixteen years of age......he is said to have committed rape.

In any case of rape the prosecution has to prove that:

a) the man who did it was the accused; and

b) the act was done against her will or that she was below 16 years of age (in this case a birth certificate is necessary)

Perhaps no one will question that the rape is one of the most common and condemnable of all the crimes against women. The cases of rapes have revealed a grim reality of the society as it has been observed that the rapes have been perpetrated upon the girl children even of 3 years of age. When a girl is raped it affects her whole personality and life, ultimately causing her suffers psychologically. The trauma leaves her in a great distress and most of the times leading to suicide. There are very complications in the cases of rape because the consequences of it lead to social, psychological, ethical and even political troubles. Parents have been taking an extraordinary care for their female children at different stages of life and it so because somewhere down the line administrative impotency over rape like crimes have made the movement of young girls terrible. Hence, it is must that stringent laws be implemented and guided by the government (Goel, 2004).

There are numbers of cruelties and harassments perpetrated upon women resulting in a lot of irreparable damages caused to the victims but the harm inflicted by rape is quite irremediable. It not only ruins the life of the victimized woman, but also affects the family as a whole. It is therefore necessary to look into this crime from a broader perspective. Rape is committed not only by the breakers of law, but also by the protectors of law. Those who are expected to protect the life and liberty of the people are themselves involved in this crime. There have been a number of cases where policemen have raped women. Gang raped by individuals and even by policemen is well known (Zehra, 1996).

Women are molested, harassed and even raped by those who are supposed to be guardians and protectors of them such as policemen, teachers, law-makers, politicians, etc. Teachers are projected as having ideal and noble character, who are builders of nation but unfortunately such an ideal image of a teacher has been lost for decades in this country. Day by day lot cases of molestation and rapes are reported against male teachers in schools, colleges and universities. The rich and high castes young men find their past time and amusement in teasing and raping young girls and women of the poor and low caste strata of the society. It has become a trend of the country to commit all sorts of crime against low and poor women of the society. Women of the low caste only are becoming the victims of crime in routine nature (Mandal, 2003).

The reported rape cases obtained from the National Crime Records Bureau for the years 1985 to 1989 are given below for all the States and the Union Territories. However, it is important to note that the figures given in the table represent only the number of cases which are reported, but in reality, the number is more than double. This is because a large number of cases are not reported due to the social stigma attached to it. 
Kaneez Zehra in her paper entitled Crimes against Women presented a table of rape cases from 1985- 1989 as furnished below in table 1:

Table 1.

Rape Cases Reported on All India basis during 1985-1989

\begin{tabular}{|c|c|c|c|c|c|}
\hline \multirow{2}{*}{ States/ U.T } & \multicolumn{5}{|c|}{ Years } \\
\hline & 1985 & 1986 & 1987 & 1988 & 1989 \\
\hline Andhra Pradesh & 409 & 428 & 497 & 545 & 583 \\
\hline Arunachal Pradesh & 5 & 9 & 11 & 17 & 21 \\
\hline Assam & 332 & 398 & 442 & 404 & 471 \\
\hline Bihar & 686 & 794 & 849 & 962 & 956 \\
\hline Goa & 9 & 8 & 12 & 20 & 16 \\
\hline Gujarat & 130 & 149 & 159 & 168 & 215 \\
\hline Haryana & 105 & 142 & 134 & 150 & 155 \\
\hline Himachal Pradesh & 33 & 52 & 34 & 45 & 60 \\
\hline Jammu \& Kashmir & 207 & 187 & 171 & 211 & 176 \\
\hline Karnataka & 121 & 133 & 167 & 193 & 170 \\
\hline Kerala & 130 & 138 & 192 & 205 & 206 \\
\hline Madhya Pradesh & 1465 & 1506 & 1705 & 1885 & 2224 \\
\hline Maharashtra & 673 & 804 & 782 & 838 & 825 \\
\hline Manipur & 17 & 10 & 11 & 8 & 13 \\
\hline Meghalaya & 16 & 19 & 19 & 16 & 20 \\
\hline Mizoram & 51 & 46 & 62 & 56 & 47 \\
\hline Nagaland & 13 & 10 & 9 & 12 & 10 \\
\hline Orissa & 154 & 172 & 186 & 183 & 196 \\
\hline Punjab & 82 & 49 & 47 & 49 & 81 \\
\hline Rajasthan & 552 & 598 & 604 & 602 & 721 \\
\hline Sikkim & 6 & 5 & 8 & 6 & 5 \\
\hline Tamil Nadu & 230 & 252 & 267 & 305 & 279 \\
\hline Tripura & 34 & 38 & 43 & 43 & 66 \\
\hline Uttar Pradesh & 1163 & 1293 & 1392 & 1385 & 1468 \\
\hline West Bengal & 597 & 612 & 632 & 631 & 575 \\
\hline Total & 9205 & 9838 & 10422 & 10927 & 11548 \\
\hline A \& N Island & 3 & 2 & 6 & 4 & 6 \\
\hline Chandigarh & 4 & 5 & 5 & 4 & 7 \\
\hline D \& N Haveli & 1 & 0 & 2 & 3 & 0 \\
\hline Delhi & 83 & 89 & 103 & 121 & 152 \\
\hline Daman \&Diu & 0 & 0 & 1 & 0 & 0 \\
\hline Lakshadeep & 8 & 5 & 7 & 5 & 6 \\
\hline Total & 99 & 101 & 124 & 137 & 171 \\
\hline Grand Total & 9304 & 9939 & 10546 & 11064 & 11719 \\
\hline
\end{tabular}

Source: (Zehra, 1996 “Crime Against Women” pp. 177-178)

Reported incidence of rape cases in India: National Crime Records Bureau (NCRB) Report 2014

Marital rape and incest are the two different forms of rape that can occur within the family. In any society a woman is prone to victimization of almost every kind of abuse. In the circumstances like armed conflict women have been observed to fall prey to any abuser, even in refugee camps women have a great menace of being raped and abused. So in present times women are seen in constant threat of being harassed in every country (Khanna, 2009).

Christin Mathew Philip, a principal correspondent with The Times of India, Chennai, published a report in Times of India on $1^{\text {st }}$ July, 2014 which says that every day 93 women are being raped in India. National Crime Records Bureau (NCRB), reports that a regular increase in the number of rapes are reported in India, i.e. from 24,923 in 2012 to 33,707 in 2013. After Nirbhaya incident in New Delhi a number of protests have been held but to no purpose, as the 
national capital city of India is still a place of threat. That's why we see a challenging increase in rapes in Delhi from 585 in 2012 to 1,441 in 2013. It can be said that a kind of competition is going on in the metropolitan cities of India to top the list of criminal records. After New Delhi, Mumbai holds second place with 391 rapes, Jaipur third with 192 rapes, and Pune fourth with 171 rapes in the during the same period. These cities are considered among the top unsafe cities of India. Madhya Pradesh has also reported the maximum number of 4,335 rape cases in 2013. Madhya Pradesh in April 2014 has witnessed a desolate fate of Dalit community as a 14 year old Dalit girl was allegedly gang raped by five men in a moving bus. According to another report published in The Hindu dated 15 June, 2014 in Madhya Pradesh a tribal woman was also allegedly gang raped by ten persons, including her husband after a land dispute. She was paraded naked and force for drink urine infront of her son. This kind of worst form of atrocities still happen in our societies. After Madhya Pradesh it is followed by Rajasthan (3285), Maharashtra (3063) and Uttar Pradesh (3050). A total 923 rape cases were reported in Tamil Nadu, which means 3 per day. Quite unfortunate to nation is the fact that majority of the perpetrators are seen as the family persons or the nearest kiths and kins of the victims. NCRB statistics shows that 31,807 (94\%) were familiar to the accused, which includes neighbours (10782), other known persons (18171), relatives (2315) and parents (539). It is also revealed that most victims are aged between 18 and 30 years $(15,556)$ and 14 and 18 years $(8,877)$. Activist argue that legal system is slow to prosecute rape cases, but officials say the number of rape cases have increased because of the awareness on the part of the victims, who come forward to lodge complaints (Philip, 2014).

Table 2.

Reported Incidents of Rape cases in India from year 2010 to 2014

\begin{tabular}{lc}
\hline Year & Rape Cases \\
\hline 2010 & 22,172 \\
2011 & 24,206 \\
2012 & 24,923 \\
2013 & 33,735 \\
2014 & 36,735 \\
\hline
\end{tabular}

Source: (Chapter-5, Crimes Against Women, p.3).

Report published in the Indian Express, dated 20 $0^{\text {th }}$ august, 2015 Recent shows that the Crime data released by the National Crime Records Bureau (NCRB) once again revealed a rise in number of rape cases against women in the national capital. The total number of rape cases in India for the year 2014 stood at 37,413. The data, which is collated by the bureau based on First Information Reports (FIRs) filed in police stations across the country, shows Delhi registered a total of 1813 cases of rape in the year 2014 as compared to 1441 in 2013 and 585 in 2012. Post the 2012 Delhi gang rape case and the consequent protests, the number of reported rapes shot up from 585 in 2012 to 1441 in 2013, a 146 per cent jump, much of which has been attributed to victims coming forward and reporting incidents refusing to be crowed down by the attached 'stigma' and victim shaming. As far second to Delhi was Mumbai, which reported a total of 607 cases of rapes in 2014, as compared to 391 in 2013. Bangalore followed with a 104 cases of rape. Chennai and Kolkata saw a drop in reported cases of rape in 2014. Chennai reported 65 cases as compared to 83 in 2013, while Kolkata reported 36 cases of rape as compared to 75 in 2013(Pereira, 2015).

It is interesting to note that in many countries sexual assault by a husband on his wife is not considered to be a crime: a wife is expected to submit to her husband. It is thus very difficult in practice for a woman to prove that sexual assault has occurred unless she can demonstrate serious injury. 


\section{Conclusion}

In India the root cause of violence against women is that traditional discrimination which exists in the society since time immemorial. There are numerous issues and challenges that women face in day-to-day life. Women are exposed to discriminatory personal laws, their segregation and isolation in family, community and society. They are victims of gender bias in a patriarchal society, discrimination at the place of their employment and wages. The extreme cases are that of physical weakness due to malnutrition, and other cases of domestic violence. Women are kept unlettered and their rising illiteracy rate becomes an alarming threat to the community as well as whole nation. There are daily cases of eve teasing, rape and murder of minor girls, abduction, forced labor, molestation, cruelty, etc. which are shockingly increasing day by day in our country. Mistreatment of women in India starts from the time of her birth. Many times boys are preferred to girls. Usually the birth of a girl child does not make even the parents of the child happy, leave alone other members of the family. On the other hand, the birth of a son is devotedly celebrated with blessings showered on the couple by all the members of the family, friends and neighbours alike. In such cases, women themselves are equally to be blamed. Though they are feminine first and anything else only in the second place, they want to have a son. Even educated women think likewise. This has to change. If a woman accidently gives birth to two or three daughters, she is made to hang her head in shame. She is subjected to abuses and all sorts of ill-treatment especially by in-laws. In most of such cases women have committed suicide being fed up with torture by mother-in-law and husband for being unable to give birth to a son for the family. This happens because of the prevailing system of patriarchal society where men are given more importance in the society than women.

\section{References}

Bhatt, S. (2010). Women and Human rights. New Delhi: Altar Publishing House

Goel, A. (2004). Violence and Protective Measures for Women Development and Empowerment. New Delhi: Deep and Deep Publications Pvt. Ltd.

Khanna, S. (2009). Violence against Women and Human Rights. Delhi: Swastik publishers \& Distributors.

Mandal, J. (2003). Women and Reservation in India. Delhi: Kalpaz Publications.

Nigam, S. (2008). Domestic Violence in India: What One Should know?. New Delhi: We the People Trust.

Pereira, A. (2015, August 20). Delhi is the rape capital; NCRB data shows rape cases up 200 $\%$ since 2012. The Indian Express. Retrieved from http://indianexpress.com/article/india/crime/delhi-is-the-rape-capital-ncrb-data-showsrape-cases-up-200-since-2012/

Philip, C.M. (2014, 1 July). 93 women are being raped in India every day, NCRB data show. The Times of India. Retrieved from http://timesofindia. indiatimes.com/india/93-womenare-being-raped-in-India-every-day-NCRB-data-show/articleshow/37566815.cms

Saikia, N. (2008). Indian Women: A Socio-Legal Perspective. New Delhi: Serials Publications.

Zehra, K. (1996). Crime Against Women. In S. Aleem (Ed.), Women's Development: Problems and Prospects. New Delhi: APH Publishing Corporation.pp.34. 